\title{
Dynamics of Tissue Ubiquitin Pools and Ubiquitin-Proteasome Pathway Component Activities during the Systemic Response to Traumatic Shock
}

\author{
M. B. PATEL, S. A. EARLE, M. MAJETSCHAK \\ Division of Trauma and Surgical Critical Care, DeWitt Daughtry Family Department of Surgery, \\ University of Miami Miller School of Medicine, Miami, USA
}

Received July 24, 2006

Accepted September 18, 2006

On-line available December 19, 2006

\begin{abstract}
Summary
Based on the biological significance of the ubiquitin-proteasome pathway (UPP) and its potential role during sepsis, burns and ischemia-reperfusion injury, we hypothesized that the systemic response to traumatic shock (TS) is accompanied by tissue-specific UPP alterations. Therefore, we studied tissue ubiquitin pools, chymotryptic- and trypticlike proteasome peptidase activities and ubiquitin-protein ligation (UbPL) rates in skeletal muscle, heart, lung, liver, spleen and kidney using a clinically relevant porcine model (bilateral femur fracture/hemorrhage followed by fluid resuscitation). TS induced a systemic reduction of tissue-specific high molecular mass ubiquitin-protein conjugates $(>50 \mathrm{kDa})$. Free ubiquitin was unaffected. The dynamic organ patterns of ubiquitin pools paralleled the typical physiological response to TS and resuscitation. Reduction of ubiquitin-protein conjugates was most pronounced in heart and lung ( $\mathrm{p}<0.05$ vs. control) and accompanied by significant increases in proteasome peptidase and UbPL activities in these organs. Unlike all other tissues, spleen proteasome peptidase and UbPL activities were significantly reduced $10 \mathrm{~h}$ after TS. These findings support the concept that the UPP could play an important role in regulation of cell functions during the early whole-body response to TS. The UPP might be a therapeutic target to improve the metabolic care after TS, particularly in the heart, lung, and spleen.
\end{abstract}

\section{Key words}

Proteasome endopeptidase complex $\bullet$ Ubiquitin-protein ligase complexes $\bullet$ ATP-dependent 26S protease $\bullet$ Epoxomicin - Traumatic shock

\section{Introduction}

Severe trauma induces an integrated metabolic response and is associated with impairment of the function of virtually all organs and tissues of the body. The net effects are a progressive increase in resting and total energy expenditure, a significant decrease in total body protein independent of the patient's energy balance, and organ dysfunction with a high risk of developing multiple organ failure and sepsis (Hasselgren 2000, Majetschak and Waydhas 2000, Plank and Hill 2000,2003, Aller et al. 2004, Keel and Trentz 2005). As 
reflected by the lack of causative therapeutic strategies, the molecular basis of this response is not well understood.

Several lines of evidence suggest that the ubiquitin-proteasome pathway may play an important role in regulating intermediary metabolism and cell function in catabolic disease states, such as sepsis, burns or ischemia-reperfusion injury. In skeletal muscle from rats with sepsis or burn injuries increased proteolysis correlated with increased mRNA levels of ubiquitin, ubiquitin activating enzyme E2 $14 \mathrm{k}$, ubiquitin protein ligase E3 $\alpha$ and proteasome subunits C2 and C3 (Fischer et al. 2000, Fang et al. 2000, Tiao et al. 1994, Hobler et al. 1999a,b, Chai et al. 2002, Shen et al. 2003). Studies in patients with sepsis and brain-injured patients with hypermetabolism and negative nitrogen balance indicated increased mRNA levels of ubiquitin, E2 $2_{14 \mathrm{k}}, \mathrm{C} 2$ and C3 in skeletal muscle (Tiao et al. 1997, Mansoor et al. 1996). Besides the possible involvement of the ubiquitinproteasome system in regulating skeletal muscle metabolism, animal studies in various species suggested that it also may contribute to ischemia-reperfusion injury in the brain, heart and liver (Keller et al. 2000, Bulreau et al. 2001, Willmore and Storey 1996) and proteasome inhibitors have been shown to diminish organ injury during reperfusion in brain, heart and kidney (Phillips et al. 2000, Campbell et al. 1999, Takaoka et al. 1999).

Recently, we detected considerable differences of the ubiquitin system among various porcine tissues in physiological baseline conditions (Patel and Majetschak 2007). Furthermore, we showed that proteasome peptidase activities are significantly elevated in direct mechanically injured human skeletal muscle (Seiffert et al. 2007). Although these findings suggested tissuespecific roles of ubiquitin-proteasome pathway components in health and disease states and showed that proteasome activation contributes to the response to direct mechanical trauma in skeletal muscle, systemic effects of trauma on the ubiquitin-proteasome system in skeletal muscle and in other tissues are still unknown. Based on its major biological role in all eukaryotic cells (Hershko and Ciechanover 1998) and its potential role in sepsis, burns and ischemia-reperfusion injury in various organs, we hypothesized that the ubiquitin-proteasome system is also involved in the initial whole-body response to severe trauma. To test this hypothesis, we studied tissue ubiquitin-proteasome pathway component activities and ubiquitin pools in skeletal muscle, heart, lung, liver, kidney, and spleen remote from the site of injury using a clinically relevant porcine model of traumatic shock.

\section{Methods}

\section{Animal protocol}

All procedures were approved by the institutional Animal Care and Use Committee and described in detail previously (Majetschak et al. 2004). Farm-raised crossbred fasted swine of both sexes (30-35 kg) were sedated with an intramuscular injection of $10 \mathrm{mg} / \mathrm{kg}$ ketamine and $1 \mathrm{mg} / \mathrm{kg}$ xylazine. Animals underwent oro-tracheal intubation and mechanical ventilation (Impact Portable Adult Ventilator Model 754 (Impact Systems, West Caldwell, NJ); tidal volumes of $12 \mathrm{ml} / \mathrm{kg}$ and $8-16$ breaths $/ \mathrm{min}$ to maintain $\mathrm{pCO}_{2}=40 \pm 5$ $\mathrm{mm} \mathrm{Hg} ; \mathrm{FiO}_{2}=0.4$ ). Anesthesia was maintained with continuous intravenous infusions of $10 \mathrm{mg} / \mathrm{kg} / \mathrm{h}$ ketamine, $0.25 \mathrm{mg} / \mathrm{kg} / \mathrm{h}$ xylazine, and $50 \mu \mathrm{g} / \mathrm{kg} / \mathrm{h}$ fentanyl. Pulse oximetry (Nellcor Pulse Oximeter, Hayward, CA) was continuously monitored. Catheters were placed in the femoral artery for continuous arterial blood pressure monitoring (Zoll Hemodynamic Monitor, Burlington, MA) and external jugular vein for intravenous fluid administration. End-tidal $\mathrm{CO}_{2}$, heart rate, MAP and central venous pressure (CVP) were monitored continuously online. Blood gases $\left(\mathrm{PaO}_{2}\right.$, $\mathrm{PCO}_{2}, \mathrm{pH}$, base excess, and arterial $\mathrm{O}_{2}$ saturation), lactate and electrolytes $\mathrm{Na}^{+}, \mathrm{K}^{+}, \mathrm{Cl}^{+}, \mathrm{Ca}^{+2}$, glucose, and osmolarity) were recorded at 30-60 min intervals on a Nova Stat Profile Ultra (Waltham, MA). Complete blood counts (hematocrit, white blood cell counts (WBC), lymphocyte, polymorphonuclear cell (PMN) and platelet count) were determined on an Abbott Cell-Dyne 1600 (Abbott Park, IL).

Animals were subjected to one of the following experimental groups:

1. Control $5 \mathrm{~h}(\mathrm{n}=5)$ : Normal saline intravenous fluid administration to maintain mean arterial pressure (MAP) of $70 \mathrm{~mm} \mathrm{Hg}$ for $5 \mathrm{~h}$.

2. Control $10 \mathrm{~h}(\mathrm{n}=5)$ : Same protocol as for group 1 for $10 \mathrm{~h}$.

3. Traumatic shock $5 \mathrm{~h}(\mathrm{n}=5)$ : Bilateral femur fractures and hemorrhage followed by normal saline intravenous fluid resuscitation to maintain a MAP of $70 \mathrm{~mm} \mathrm{Hg}$ for $5 \mathrm{~h}$.

4. Traumatic shock $10 \mathrm{~h}(\mathrm{n}=5)$ : Same protocol as for group 3 for $10 \mathrm{~h}$. 
In the trauma groups (groups 3 and 4) bilateral femur fractures were produced with a captive bolt gun followed by a hemorrhage to a MAP of $25 \pm 1 \mathrm{~mm} \mathrm{Hg}$ for $40 \mathrm{~min}$, as described previously (Majetschak et al. 2004). During this shock period $\mathrm{FiO}_{2}$ was 0.21 .

At the end of observation, animals were sacrificed and uninjured vastus medialis muscle (fast glycolytic muscle with $\sim 70 \%$ type IIb fibers) (Rusunen and Puolanne 1997), heart (left ventricle), lung, liver, spleen, and kidney harvested, snap frozen in liquid nitrogen, and stored at $-80{ }^{\circ} \mathrm{C}$.

\section{Preparation of tissue extracts}

Tissues were homogenized in ice-cold $1 / 10$ phosphate buffered saline, $\mathrm{pH} 7.4$ (1:5; volume:volume) using a Brinkmann-Polytron-homogenizer (Best-LabDeals, Raleigh,NC,USA). Homogenates were centrifuged $\left(20000 \mathrm{~g}, \quad 5^{\circ} \mathrm{C}, \quad 30 \mathrm{~min}\right)$, supernatants (= extracts) aliquoted, and total protein concentration measured (Lowry et al. 1951). One aliquot was immediately used for peptidase assays; all others were stored frozen at $-80{ }^{\circ} \mathrm{C}$ until further analysis.

\section{Western blot analyses}

Immunoblotting to ubiquitin with an antiubiquitin antibody and densitometric quantification was described in detail previously (Majetschak et al. 2003, Ponelies et al. 2005, Patel and Majetschak 2007). In brief, $50 \mu \mathrm{g}$ extract proteins were separated by SDSpolyacrylamide gel electrophoresis (4-15\% Tris-HCl gradient gels, Bio-Rad, Hercules, Ca, USA), transferred to PVDF membranes and probed for ubiquitin with antiubiquitin (1:800, Sigma, St. Louis, MO, USA) and a corresponding horseradish peroxidase-labeled secondary antibody (1:10000, Amersham, Piscataway, NJ, USA). Visualization and quantification of immunoreactive proteins was performed with chemiluminescence detection (Super-Signal, Pierce, Rockford, IL, USA) using the ImageMaster VDS-CL system with the ImageQuant TL analysis software (Amersham). Chemiluminescence signals were compared only within each individual gel. Each gel contained a lane with an extract from the control group (control $=100 \%$ ) and the corresponding trauma group obtained at $5 \mathrm{~h}$ or $10 \mathrm{~h}$, respectively. Dye stain analysis (MemCode Reversible Protein Stain, Pierce, Rockford, IL, USA) and re-probing the membranes with an anti-actin antibody and a corresponding anti-rabbit horseradish peroxidaselabeled antibody were performed as controls for the protein transfer to the blotting membranes.

Immunoblots were further used to analyze the molecular mass distribution of ubiquitin protein conjugates. After immunoblotting to ubiquitin and chemiluminescence detection, pixel densities of each lane were plotted against the Rf [(distance of protein migration) / (distance of tracking dye migration)] value and spline curves calculated. For each gel the corresponding molecular masses were calculated using the Rf-values of protein standards (Precision Plus Protein Standards, Bio-Rad). To evaluate the influence of traumatic shock on the molecular mass distribution of ubiquitin protein conjugates net molecular mass profiles (pixel density of the trauma group minus pixel density of the corresponding control group) were calculated for each gel, normalized using an ubiquitin standard (10 ng) which was run on each gel and plotted as mean \pm S.E.M. for each group.

\section{Peptidase assays}

Peptidase activities were measured employing the fluorogenic peptide substrates $N$-Suc-Leu-Leu-ValTyr-7-amino-4-methylcoumarin (chymotryptic-like, CT-L) and Bz-Val-Gly-Arg-7-amino-4-methylcoumarin (tryptic-like, T-L) (both from Plymouth Meeting, PA, USA), as described recently (Patel and Majetschak 2007). Reaction mixtures contained $1 \mathrm{mM}$ DTE, $1 \mathrm{mM}$ ATP, $5 \mathrm{mM} \mathrm{MgCl}_{2}, 10 \mathrm{mM}$ Tris/HCl, $\mathrm{pH} 8.0,100 \mu \mathrm{M}$ peptide substrate and $0.6 \mathrm{mg} / \mathrm{ml}$ tissue extract. Mixtures were incubated for $60 \mathrm{~min}$ at $37^{\circ} \mathrm{C}$. Ethanol (2:1; volume:volume) was added, mixtures placed on ice for $10 \mathrm{~min}$ and centrifuged at $16000 \mathrm{~g}, 5^{\circ} \mathrm{C}$ for $6 \mathrm{~min}$. Supernatants were transferred into microplates (Corning, Acton, MA, USA) and free 7-amino-4-methylcoumarin cleaved from the substrates measured in a fluorescence reader (FLX8000, Biotek, Woburn, MA, $\lambda$ excitation/emission = $360 / 455 \mathrm{~nm})$ against standard curves of 7-amino-4methylcoumarin (Sigma). To differentiate the $\mathrm{Mg}^{2+} / \mathrm{ATP}-$ dependent 26S-proteasome from other peptidase activities, the $\mathrm{Mg}^{2+} / \mathrm{ATP}$ - and epoxomicin (specific proteasome inhibitor)dependent proportion was determined by addition of $10 \mathrm{mM}$ EDTA (Eytan et al. 1993; Sigma) and $7 \mu \mathrm{M}$ epoxomicin (Meng et al. 1999; Boston Biochem, Cambridge, MA) to the mixtures. Proteasome peptidase activity, determined as mol of 7-amino-4-methylcoumarin cleaved per second and mg protein, was calculated (total peptidase activity minus activity in the presence of EDTA and epoxomicin) and expressed as percent of the control group ([activity ${ }_{\text {trauma }} /$ activity $\left._{\text {control }}\right] \mathrm{x}$ 100). Enzyme time-progression curves showed linearity for 
A

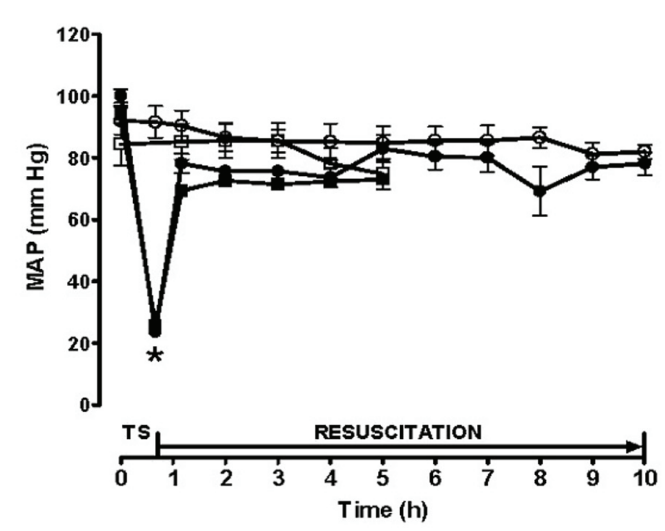

C

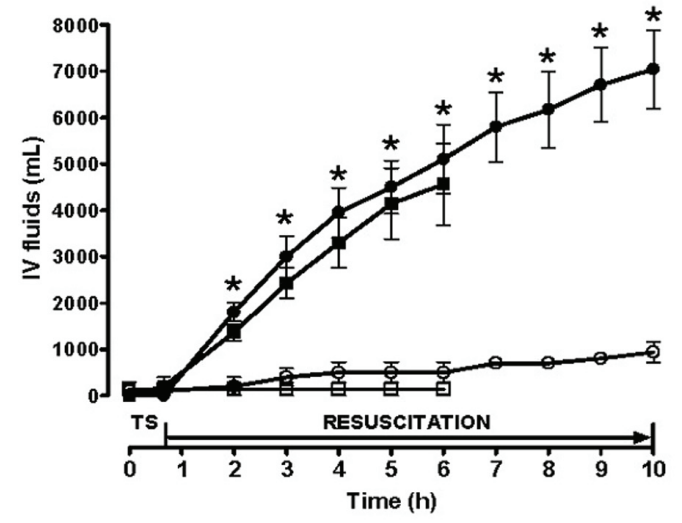

E

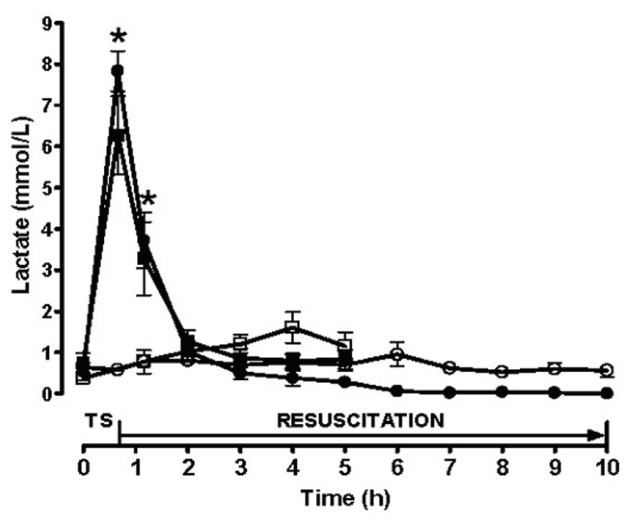

B

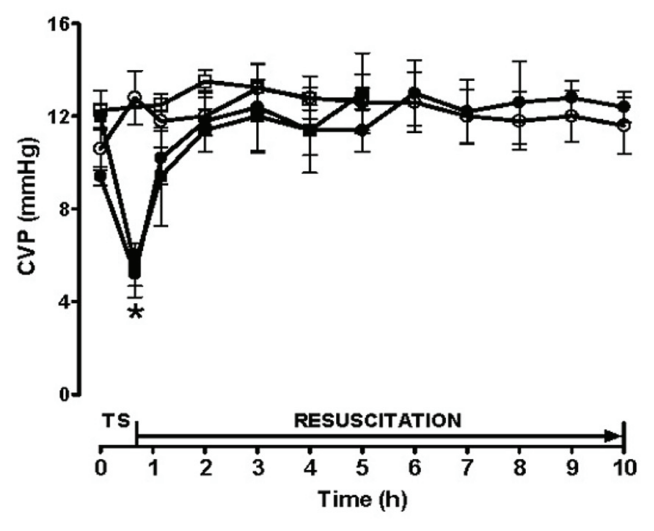

D

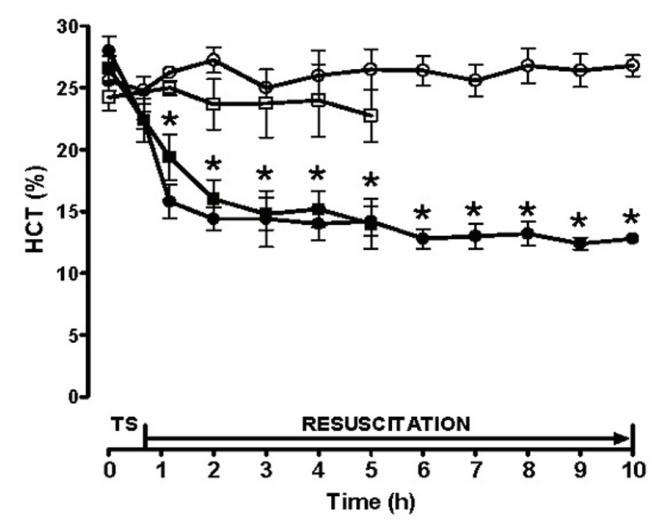

Fig. 1. Physiological chara-cteristics. TS: Traumatic shock period (40 min; bilateral femur fractures plus hemorrhage to a mean arterial pressure (MAP) of $25 \mathrm{~mm} \mathrm{Hg}$ ). Resuscitation: Intravenous fluid resuscitation to maintain MAP of $70 \mathrm{~mm} \mathrm{Hg}$. $\square$ : Control $5 \mathrm{~h} \mathrm{O}$ : Control $10 \mathrm{~h}$. $\mathbf{~ : ~ T r a u m a t i c ~ s h o c k ~} 5 \mathrm{~h}$. Traumatic shock $10 \mathrm{~h} . \mathrm{N}=5$ per group. A. Mean arterial pressure (MAP). B. Central venous pressure (CVP). C. IV fluids: Cumulative intravenous fluid requirements to maintain a MAP of at least $70 \mathrm{~mm} \mathrm{Hg}$. D. Hematocrit (HCT). E. Blood lactate concen-trations. $* \mathrm{p}<0.05$ vs. $5 \mathrm{~h}$ and $10 \mathrm{~h}$ control group. Data are mean \pm S.E.M. $(n=5)$.

$60 \mathrm{~min}$ for both peptidase activities. Since pilot experiments showed that proteasome peptidase activities were inactivated by a single freeze $\left(-80^{\circ} \mathrm{C}\right)$-thaw cycle, all peptidase activities were measured immediately in freshly prepared tissue extracts.

\section{Ubiquitin-protein ligation rates (UbPL)}

The total UbPL in tissue extracts (final protein concentration $2.5 \mathrm{mg} / \mathrm{ml}$ ) were measured as incorporation of biotinylated ubiquitin (Boston Biochem) into the sum of the extract proteins, as described in detail previously (Majetschak et al. 2000, Ponelies et al. 2005, Seiffert et al. 2007, Patel and Majetschak 2007). Ubiquitin protein ligation rates were calculated as mol of biotinylated ubiquitin conjugated to extract proteins per second and $\mathrm{mg}$ of protein and expressed as percent of the control group ([activity trauma activity $\left._{\text {control }}\right] \times 100$ ).

\section{Statistics}

Data are described as the mean \pm SEM. One-way 
A

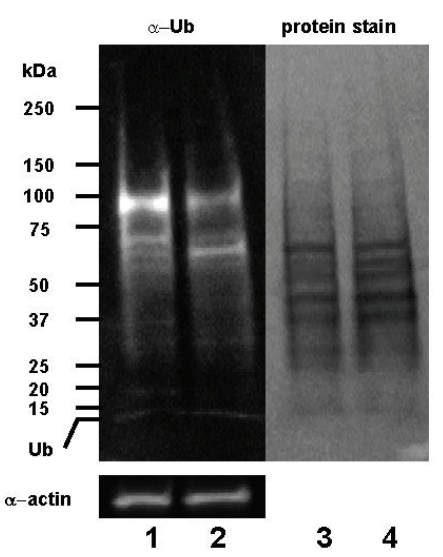

B

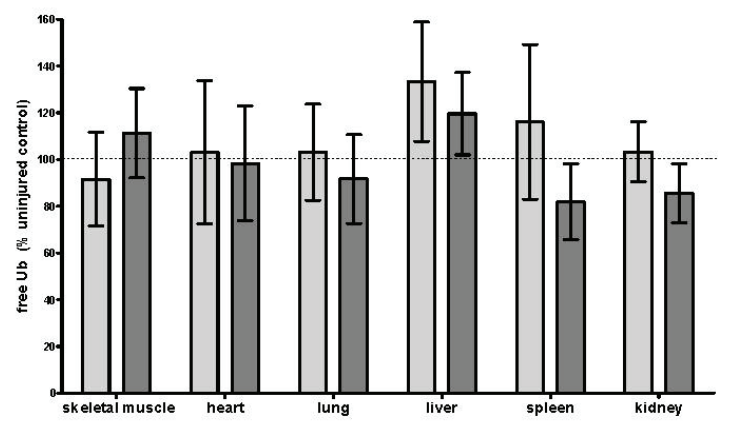

C

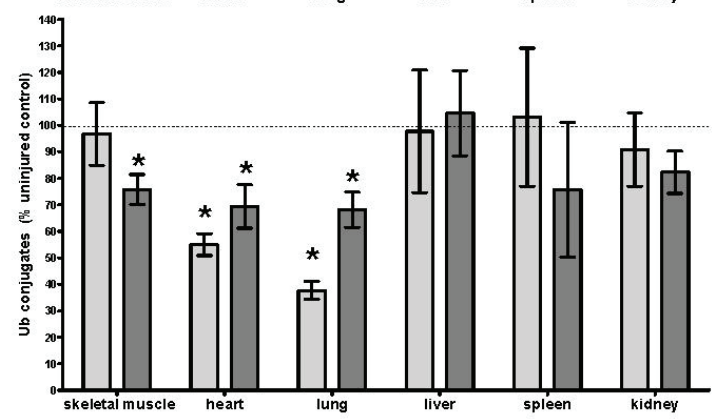

Fig. 2. A. Example of a tissue extract (heart at $10 \mathrm{~h}$ ) with reduced overall levels of ubiquitin protein conjugates after trauma and resuscitation. $\alpha$-actin: Re-probing of the membrane with anti-actin as additional protein loading control. Lane 1: 50 $\mu \mathrm{g}$ of heart lysate, control $10 \mathrm{~h}$. Lane $2: 50 \mu \mathrm{g}$ of heart lysate, trauma $10 \mathrm{~h}$. Lane 3: Total protein staining of lane 1 (protein loading control). Lane 4: Total protein staining of lane 2 (protein loading control). Left: Molecular mass standards. Ub: Ubiquitin. B. and C. Quantification of free (B) and conjugated ubiquitin (C) tissue levels by densitometry obtained from immunoblotting experiments. Tissue levels are given as \% of the corresponding control group (data are mean \pm S.E.M.). Light columns: Tissues harvested at $5 \mathrm{~h}$ after trauma $(n=5)$. Dark columns: Tissues harvested at $10 \mathrm{~h}$ after trauma $(n=5)$. Muscle: Skeletal muscle. Dashed line: mean tissue levels of the control group $(=100 \%$, $\mathrm{n}=5$ per time point). Ub: Ubiquitin. $* \mathrm{p}<0.05$ vs. control.

ANOVA and t-test for independent samples were calculated with the SPSS 13.0 for Windows program (SPSS Inc., Chicago, IL). Regression analyses and spline curves were calculated with the Prism 4 (version 4.03) for Windows program (GraphPad-Software, San Diego, CA). A two-tailed $p<0.05$ was considered significant.

\section{Results}

\section{Animal characteristics}

Under the baseline conditions prior to injury, there were no differences in any of the measured physiological parameters between the groups. All parameters were within the normal range.

To maintain systemic hemodynamics after traumatic shock (Figs $1 \mathrm{~A}$ and 1B), animals required $4.8 \pm 0.51$ of fluids by $5 \mathrm{~h}(\mathrm{n}=10)$ and $7.4 \pm 0.61$ by $10 \mathrm{~h}$ $(n=5)$ (Fig. 1C). Hematocrit (baseline 26 $\pm 3 \%$ ) decreased in the trauma group to $14 \pm 0.8 \%$ at $5 \mathrm{~h}$ and $13 \pm 0.4 \%$ at $10 \mathrm{~h}$ (Fig. 1D). In the control groups, fluid requirements were minimal $-0.3 \pm 0.11$ by $5 \mathrm{~h}(\mathrm{n}=10)$ and $0.8 \pm 0.21$ by $10 \mathrm{~h}(\mathrm{n}=5)$; hematocrit and lactate levels were stable. In the trauma groups, at the end of the hemorrhage period, lactate levels were $7.2 \pm 0.7 \mathrm{mmol} / \mathrm{l}(\mathrm{n}=10)$ and normalized in all animals within $5 \mathrm{~h}(<2 \mathrm{mmol} / \mathrm{l})$ (Fig. 1E). All other physiologic parameters were similar between the trauma and control groups (data not shown).

\section{Ubiquitin pools}

Figure 2A shows a representative example for the analysis of trauma-associated changes of the tissue ubiquitin pools with heart extracts obtained at $10 \mathrm{~h}$. While free ubiquitin appeared unchanged between the control and trauma group, ubiquitin protein conjugates were clearly decreased (Fig. 2A, lane 2). Dye stain analysis for total protein showed similar protein loading of the individual lanes and molecular mass distribution of the extract proteins (Fig. 2A, lanes 3 and 4).

The quantification of the chemiluminescence signals for free and total conjugated ubiquitin (Figs 2B and $2 \mathrm{C}$ ) confirmed this observation and showed that tissue levels of free ubiquitin were not significantly altered after trauma in any of the tissue extracts (Fig. 2B). In contrast, we detected a significant decrease in ubiquitin protein conjugates in the heart and lung at $5 \mathrm{~h}$ and $10 \mathrm{~h}$, and in skeletal muscle at $10 \mathrm{~h}$ after traumatic shock.

To further investigate whether changes in total ubiquitin protein conjugate levels after trauma can be attributed to alterations in specific conjugates, we analyzed the separation pattern of ubiquitin protein conjugates after gel electrophoresis and immunoblotting. Figure 3A shows the molecular mass profiles in heart extracts at $10 \mathrm{~h}$ in the control (top) and trauma group (bottom), while Figure 3B depicts the net molecular mass profile (mean pixel density of the trauma group minus mean pixel density of the control group), as a typical 


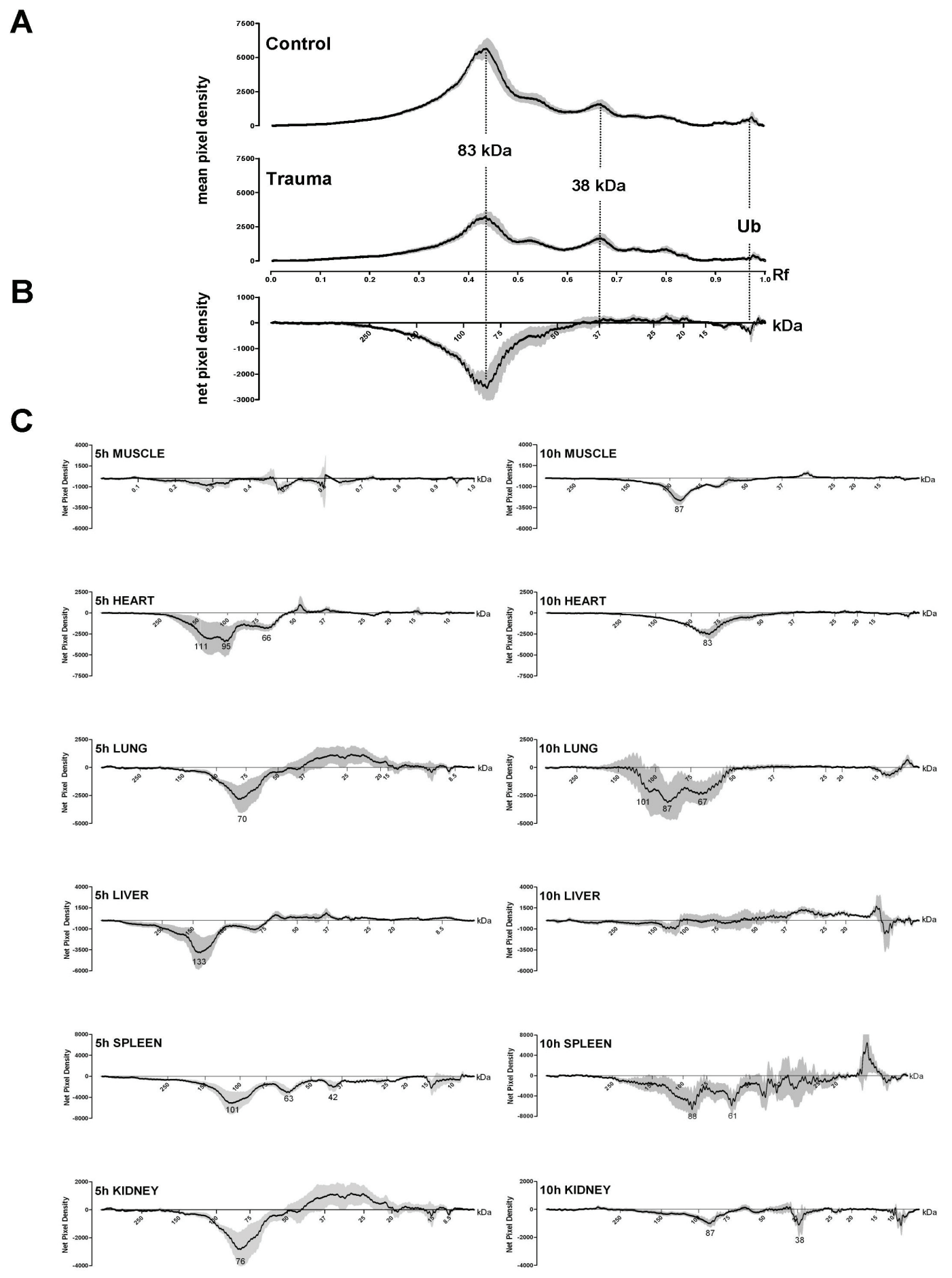

Fig. 3. Molecular mass profiles of ubiquitin protein conjugates in tissue extracts $A$. and $B$. Example for the analysis of the separation pattern of ubiquitin protein conjugates in tissue extracts (heart extracts, $10 \mathrm{~h}$ ). After immunoblotting to ubiquitin and chemiluminescence detection, pixel densities of each lane were normalized using the pixel density of the ubiquitin standard. To obtain a molecular mass profile, a spline curve was calculated and plotted against the Rf ([distance of protein migration] / [distance of tracking dye migration]) value. For each gel the corresponding molecular masses were calculated using the Rf-values of protein standards. A. Top: Molecular mass profile of the separation pattern of ubiquitin protein conjugates in heart extracts from the control group at $10 \mathrm{~h}$. Data are mean pixel density (black line) \pm SEM (gray shading); $n=5$. Bottom: Molecular mass profile of the separation pattern of ubiquitin protein conjugates in heart extracts from the trauma group after 10 hours of resuscitation. Data are mean pixel density (black line) \pm SEM (gray shading); $n=5$. B. For the analysis of trauma-induced alterations in ubiquitin protein conjugates the net molecular mass profile (pixel density of the trauma group minus pixel density of the control group; mean $\pm \mathrm{SEM}$ ) resulting from A. was calculated. The abscise axis shows the migration position and molecular masses of the protein standards, which correspond to the Rf-values in A. Main peaks are marked (vertical dashed lines) and labeled with the corresponding molecular masses. Ub: Migration position of free ubiquitin. C. Net molecular mass profiles of ubiquitin protein conjugates in tissue extracts at $5 \mathrm{~h}$ (left) and $10 \mathrm{~h}$ (right) after traumatic shock. Ordinate axis: Pixel density of the fluorescence signal (mean (black line) \pm SEM (gray shading). The abscise axis shows the migration position and molecular masses of the protein standards. 

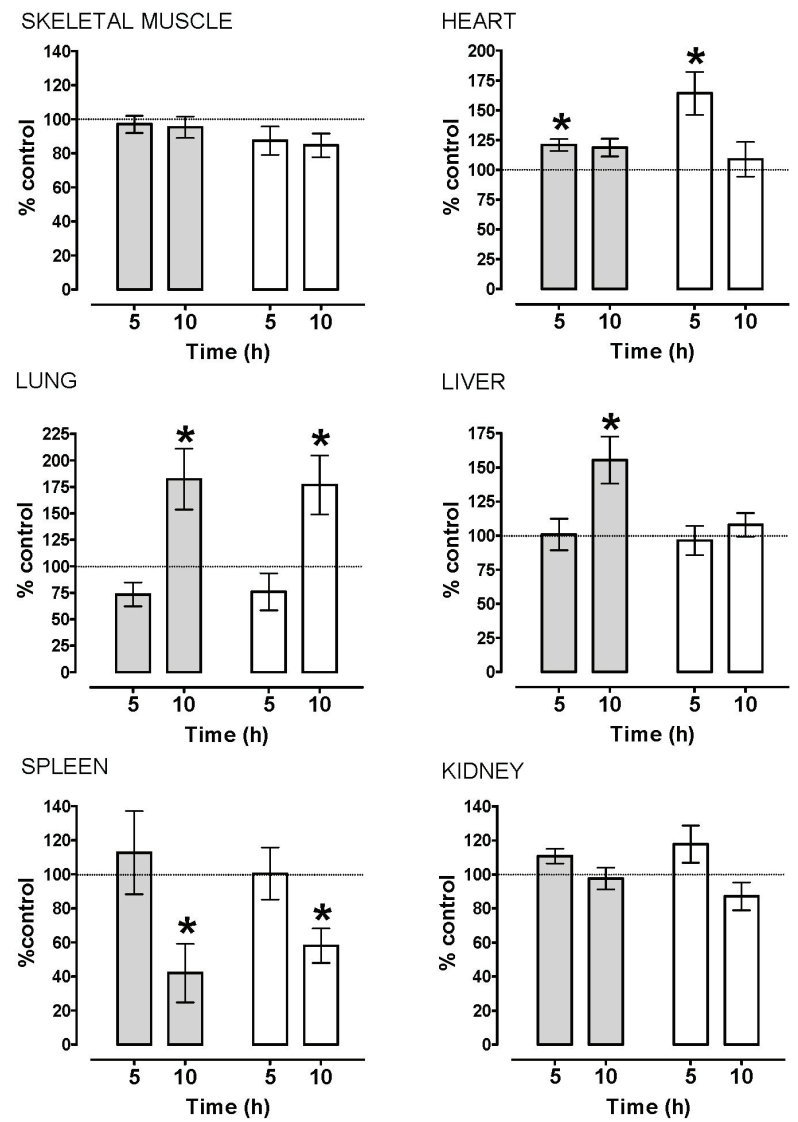

Fig. 4. Proteasome peptidase activities after traumatic shock in percent of the corresponding control groups. Proteasome activity was discriminated measuring the $\mathrm{Mg}^{2+}$ /ATP- and epoxomicindependent proportion of total tissue extract peptidase activities. Shaded columns: Chymotryptic-like proteasome peptidase activity. Open columns: Tryptic-like proteasome peptidase activity. Dashed line: Mean proteasome peptidase activity of the control group ( $=100 \%, \mathrm{n}=5$ per time point). $* \mathrm{p}<0.05$ vs. control. Data are mean \pm S.E.M.

example. A peak corresponding to a molecular mass of $83 \mathrm{kDa}$ clearly decreased in intensity in the trauma group, resulting in an inverse peak at this position in the net profile (Fig. 3B). In contrast, the profile in the lower molecular mass range $(<50 \mathrm{kDa})$ was unchanged.

Figure $3 \mathrm{C}$ shows the net molecular mass profilesof the ubiquitin protein conjugates for the comparison of the control groups with the trauma groups at $5 \mathrm{~h}$ and $10 \mathrm{~h}$, respectively. The molecular mass profiles did not show peaks that were unique for trauma in any of the tissue extracts. In all tissue extracts except skeletal muscle high molecular mass ubiquitin-protein conjugates (50-140 kDa) decreased at $5 \mathrm{~h}$ after trauma and gradually approached control values at $10 \mathrm{~h}$. In skeletal muscle the ubiquitin-protein conjugate profile was unchanged at $5 \mathrm{~h}$ and showed a decrease in high molecular mass ubiquitinprotein conjugates $(87 \mathrm{kDa})$ at $10 \mathrm{~h}$ after trauma.

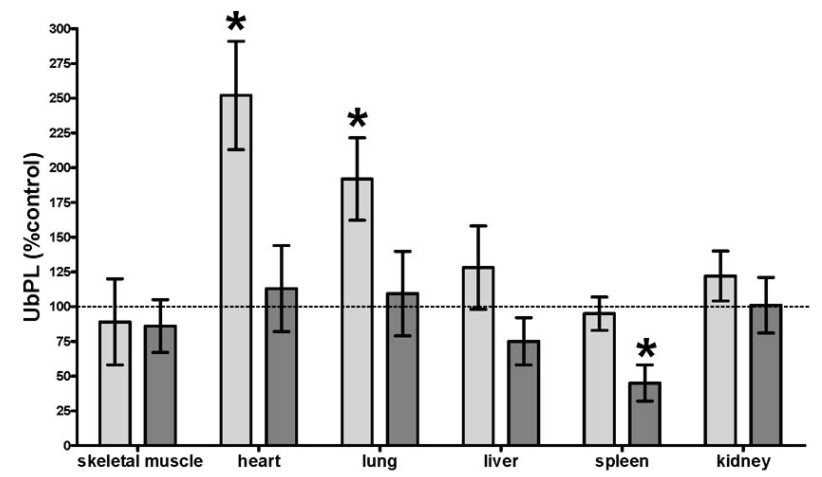

Fig. 5. Ubiquitin protein ligation rates (UbPL) after traumatic shock. UbPL are expressed as percent of the corresponding control group. Light columns: Tissues harvested at $5 \mathrm{~h}$ after trauma $(n=5)$. Dark columns: Tissues harvested at $10 \mathrm{~h}$ after trauma $(n=5)$. Muscle: Skeletal muscle. Dashed line: mean tissue levels of the control group ( $=100 \%, n=5$ per time point). $* p<0.05$ vs. control. Data are mean \pm S.E.M.

\section{Proteasome peptidase activities}

In the control groups chymotryptic-like proteasome peptidase activities $\left(\mathrm{pmol} \cdot \mathrm{s}^{-1} \cdot \mathrm{mg}^{1}, \mathrm{n}=5\right.$ per tissue) were $1140 \pm 130$ at $5 \mathrm{~h}$ and $895 \pm 46$ at $10 \mathrm{~h}$ in skeletal muscle, $3540 \pm 144$ and $3040 \pm 162$ in heart, $1093 \pm$ 121 and $803 \pm 123$ in lung, $1873 \pm 362$ and $1421 \pm 181$ in liver, $2908 \pm 182$ and $5060 \pm 72$ in kidney and $1192 \pm 341$ and $1567 \pm 267$ in spleen at $5 \mathrm{~h}$ and $10 \mathrm{~h}$, respectively. Tryptic-like proteasome peptidase activities $\left(\mathrm{pmol} . \mathrm{s}^{-1}\right.$. $\mathrm{mg}^{1}, \mathrm{n}=5$ per tissue) in tissue extracts of the control groups at $5 \mathrm{~h}$ and $10 \mathrm{~h}$ were $222 \pm 24$ and $251 \pm 31$ in skeletal muscle, $962 \pm 138$ and $1188 \pm 63$ in heart, $388 \pm 92$ and $330 \pm 35$ in lung, $526 \pm 65$ and $571 \pm 35$ in liver, $630 \pm 165$ and $660 \pm 24$ in kidney, and $310 \pm 52$ and $368 \pm 28$ in spleen.

The proteasome peptidase activities of the individual tissue extracts at 5 and $10 \mathrm{~h}$ after trauma relative to the corresponding control groups are shown in Figure 4. Proteasome peptidase activities were not significantly affected by trauma in skeletal muscle and kidney. In contrast, proteasome peptidase activities were significantly altered after trauma in the heart, lung, liver and spleen. While chymotryptic and tryptic-like proteasome peptidase activities in the heart increased at $5 \mathrm{~h}$ and returned to baseline at $10 \mathrm{~h}$ after trauma, in the lung both proteasome peptidase activities significantly increased $10 \mathrm{~h}$ after trauma. In the liver only the chymotryptic-like proteasome activity was significantly elevated at $10 \mathrm{~h}$ after trauma, whereas tryptic-like proteasome activity was unchanged. Unlike all other tissues, chymotryptic- and tryptic-like proteasome peptidase activities significantly decreased at $10 \mathrm{~h}$ after trauma in spleen. 


\section{Ubiquitin-protein ligation}

Figure 5 shows the total UbPL in the tissue extracts after trauma relative to the control groups. Significant trauma-associated changes in UbPL were not detectable in skeletal muscle, liver and kidney. In heart and lung extracts UbPL was significantly increased at $5 \mathrm{~h}$ and returned to levels of the uninjured control group at $10 \mathrm{~h}$ after trauma. Similarly to the findings on proteasome peptidase activity measurements, spleen was the only tissue in which UbPL were significantly decreased $10 \mathrm{~h}$ after trauma.

\section{Discussion}

This is the first demonstration that the ubiquitinproteasome system is systemically altered following traumatic shock in a clinically relevant animal model. Traumatic shock induced a systemic reduction of tissuespecific high molecular mass ubiquitin-protein conjugates (>50 kDa), whereas tissue levels of free ubiquitin were not affected. This reduction was most pronounced in heart and lung and accompanied by significant increases in proteasome peptidase and UbPL activities in these organs. In contrast to all other tissues, trauma induced a significant reduction of proteasome peptidase and UbPL activities in the spleen.

A combined insult of bilateral femur fracture plus hemorrhage followed by standard intensive care treatment created a pathophysiological condition in the laboratory that was similar to that in blunt trauma patients. As most commonly seen in patients with severe orthopedic trauma, these animals were fluid-dependent and hemodynamically unstable. The initial lactate levels after the shock period of approx. $7 \mathrm{mmol} / 1$ underscore the injury severity (Manikis et al. 1995, Moomey et al. 1999).

Several previous studies on ubiquitinproteasome system alterations suggested that mRNA levels of components of the multiple enzymes in this pathway do not necessarily reflect protein expression or enzyme activities (Hasselgren 2000, Jagoe and Goldberg 2001, DeRuisseau et al. 2005). Therefore, in this study, we used a classical biochemical approach for the assessment of the ubiquitin-proteasome system, measuring protein levels and enzyme activities in cell free extracts. The limitations of these measurements have been discussed in detail recently (Seiffert et al. 2007, Patel and Majetschak 2007).

The finding of this study that free ubiquitin tissue levels were maintained in all organs and tissues examined is in agreement with the deleterious effects of free ubiquitin depletion described previously (Hanna et al. 2003). We recently reported that levels of conjugated ubiquitin significantly decreased in human peripheral blood mononuclear cells, while free ubiquitin remained unchanged during sepsis (Ponelies et al. 2005). Thus, impaired ubiquitin homeostasis with a decline of ubiquitin protein conjugate levels in response to inflammatory stimuli, such as sepsis or severe injury and resuscitation, may represent a uniform cellular response of tissue- and organ-specific magnitude. From a clinical standpoint, the dynamic organ pattern of the cellular ubiquitin pools paralleled the typical physiological response to severe trauma and resuscitation in animals and patients, in which hemodynamic instability and third spacing of fluids into tissues as clinical correlates for the systemic response to trauma usually resolve with adequate fluid resuscitation.

While formation of ubiquitin chains has been shown to signal the target protein for the $26 \mathrm{~S}$ proteasome, monoubiquitylation fulfills non-catabolic functions (Hicke 2001, Sigismund et al. 2004). Although detection of conjugated ubiquitin does not differentiate multiubiquitin chains, multi-site monoubiquitylation or monoubiquitylation, the finding that exclusively higher molecular mass conjugates were reduced after trauma could suggest that these proteins preferentially consisted of $26 \mathrm{~S}$ proteasome substrates and support our finding of proteasome peptidase activity activation in heart, lung and liver. This assumption would be consistent with the finding that proteasome inhibition causes accumulation of high molecular mass ubiquitin-protein conjugates (Meng et al. 1999).

On the other hand, systemic reduction of high molecular mass ubiquitin-protein conjugates was most pronounced at $5 \mathrm{~h}$ after trauma, while at this time point increased proteasome peptidase activities were detectable only in the heart. One possible explanation for this lack of correlation could be a lower sensitivity of the proteasome peptidase assay to detect significant alterations. However, it has been shown previously that the influence of the proteasome on the regulation of cellular ubiquitin pools is probably small and that ubiquitin protein ligase systems and de-ubiquitylating enzymes are likely to be the major determinants of ubiquitin homeostasis (Haas and Bright 1987, Patel and Majetschak 2007). Since UbPL activity was significantly increased in heart and lung and unchanged in all other tissues at this time point, the 
results of the present study could point towards a decisive role of de-ubiquitylating enzymes after traumatic shock (Weissman 2001, Ponelies et al. 2005).

In agreement with previous findings from other investigators in murine splenic B-lymphocytes (Samy et al. 1999), tryptic- and chymotryptic-like proteasome peptidase activities were significantly reduced after traumatic shock in spleen. In connection with the significant reduction of the UbPL activity, these findings suggest that the ubiquitin-proteasome pathway regulation is distinct from other tissues in the immune system and may reflect the profound immunosuppression which occurs after trauma and hemorrhage in patients and has also been shown previously in this model (Majetschak et al. 2004).

In contrast to direct mechanically injured skeletal muscle (Seiffert et al. 2007), in the present study we were unable to detect significant alterations in proteasome peptidase and UbPL activities in skeletal muscle remote from the site of injury at similar time points. Although we cannot exclude proteasome activation or attenuation of UbPL activity in skeletal muscle at later time points or with higher overall severity of injury, these findings indicate distinct direct and remote effects of trauma on the ubiquitin-proteasome system. They further support the hypothesis that the ubiquitin-proteasome system might be a therapeutic target to influence muscle loss in critically ill blunt trauma patients, in which large proportions of muscle are exposed to direct trauma (Seiffert et al. 2007).

Based on the physiological tissue distribution of the ubiquitin system, we recently inferred the lung as an organ in which perturbations of ubiquitin-proteasome pathway components may contribute to disease processes (Patel and Majetschak 2007). The significant effects of traumatic shock on the lung ubiquitin-proteasome pathway now provide further evidence for this hypothesis. Similarly and in line with previous reports on the contribution of the ubiquitin-proteasome system to ischemia-reperfusion injury of the heart (Campbell et al. 1999, Bulreau et al. 2001), the findings from the present study also infer a pathophysiological role of the myocardial ubiquitin-proteasome pathway during the early whole-body response to trauma.

In conclusion, the present study shows tissuespecific alterations of cellular ubiquitin pools and ubiquitin-proteasome pathway component activities during the early post-traumatic period. These findings support the concept that the ubiquitin-proteasome system could play an important role in regulation of cell functions during the early whole-body response to trauma. If this concept can be confirmed, strategies which target the ubiquitin system could promote reestablishing ubiquitin homeostasis as a novel approach to improve the metabolic care after severe trauma and in critical illness, particularly in the heart, lung and spleen.

\section{Acknowledgements}

We thank Lissette T. Busby for excellent technical help. This research was supported in part by a grant from the Deutsche Forschungsgemeinschaft (DFG MA 2-2 to M.M.) and funds from the DeWitt Daughtry Family Department of Surgery.

\section{References}

ALLER MA, ARIAS JL, NAVA MP, ARIAS J: Posttraumatic inflammation is a complex response based on the pathological expression of the nervous, immune, and endocrine functional systems. Exp Biol Med 229: 170$181,2004$.

BULREAU AL, LUNDBERG KC, HUMPHRIES KM, SADEK HA, SZWEDA PA, FRIGUET B, SZWEDA LI: Oxidative modification and inactivation of the proteasome during coronary occlusion/reperfusion. $J$ Biol Chem 276: 30057-30063, 2001.

CAMPBELL B, ADAMS J, SHIN YK, LEFER AM: Cardioprotective effects of a novel proteasome inhibitor following ischemia and reperfusion in the isolated perfused rat heart. J Mol Cell Cardiol 31: 467-476, 1999.

CHAI J, WU Y, SHENG Z: The relationship between skeletal muscle proteolysis and ubiquitin-proteasome proteolytic pathway in burned rats. Burns 28: 527-533, 2002.

DERUISSEAU KC, KAVAZIS AN, DEERING MA, FALK DJ, VAN GAMMEREN D, YIMLAMAI T, ORDWAY GA, POWERS SK: Mechanical ventilation induces alterations of the ubiquitin-proteasome pathway in the diaphragm. J Appl Physiol 98: 1314-1321, 2005. 
EYTAN E, ARMON T, HELLER H, BECK S, HERSHKO A: Ubiquitin C-terminal hydrolase activity associated with the 26 S protease complex. J Biol Chem 268: 4668-4674, 1993.

FANG CH, SUN X, LI BG, FISCHER DR, PRITTS TA, PENNER G, HASSELGREN PO: Burn injuries in rats upregulate the gene expression of the ubiquitin-conjugating enzyme $\mathrm{E}_{14 \mathrm{k}}$ in skeletal muscle. $J$ Burn Care Rehabil 21: 528-534, 2000.

FISCHER D, SUN X, GANG G, PRITTS T, HASSELGREN PO: The gene expression of ubiquitin ligase E3 $\alpha$ is upregulated in skeletal muscle during sepsis in rats-potential role of glucocorticoids. Biochem Biophys Res Commun 267: 504-508, 2000.

HAAS AL, BRIGHT PM: The dynamics of ubiquitin pools within cultured human lung fibroblasts. $J$ Biol Chem 262: 345-351, 1987.

HANNA J, LEGGETT DS, FINLEY D: Ubiquitin depletion as a key mediator of toxicity by translational inhibitors. Mol Cell Biol 23: 9251-9261, 2003.

HASSELGREN PO: Catabolic response to stress and injury: implications for regulation. World J Surg 24: 1452-1459, 2000.

HERSHKO A, CIECHANOVER A: The ubiquitin system. Annu Rev Biochem 67: 425-479, 1998.

HICKE L: Protein regulation by monoubiquitin. Nat Rev Mol Cell Biol 2: 195-201, 2001.

HOBLER SC, WANG JJ, WILLIAMS AB, MELANDRI F, SUN X, FISCHER JE, HASSELGREN PO: Sepsis is associated with increased ubiquitin conjugating enzyme E2 ${ }_{14 \mathrm{k}} \mathrm{mRNA}$ in skeletal muscle. Am J Physiol 276: R468-R473, 1999a.

HOBLER SC, WILLIAMS A, FISCHER D, WANG JJ, SUN X, FISCHER JE, MONACO JJ, HASSELGREN PO: Activity and expression of the $20 \mathrm{~S}$ proteasome are increased in skeletal muscle during sepsis. Am J Physiol 277: R434-R440, 1999b.

JAGOE RT, GOLDBERG AL: What do we really know about the ubiquitin-proteasome pathway in muscle atrophy? Curr Opin Clin Nutr Metab Care 4: 183-190, 2001.

KEEL M, TRENTZ O: Pathopysiology of polytrauma. Injury 36: 691-709, 2005.

KELLER JN, HUANG FF, ZHU H, YU J, HO YS, KINDY TS: Oxidative stress-associated impairment of proteasome activity during ischemia-reperfusion injury. J Cereb Blood Flow Metab 20: 1467-1473, 2000.

LOWRY OH, ROSEBROUGH NJ, FARR AL, RANDALL RJ: Protein measurement with the Folin phenol reagent. J Biol Chem 193: 265-275, 1951.

MAJETSCHAK M, SUCIU DM, HASLER K, OBERTACKE U, SCHADE FU, JENNISSEN HP: Cytosolic protein ubiquitylation in normal and endotoxin stimulated human peripheral blood mononuclear cells. $J$ Endotoxin Res 6: 483-488, 2000.

MAJETSCHAK M, WAYDHAS C: Infection, bacteremia, sepsis and the sepsis syndrome - metabolic alterations, hypermetabolism, and cellular alterations. In: Multiple Organ Failure: Pathophysiology, Prevention, and Therapy. BAUE AE, FAIST E, FRY DE (eds), Springer, New York, 2000, pp 101-107.

MAJETSCHAK M, KREHMEIER U, BARDENHEUER M, DENZ C, QUINTEL M, VOGGENREITER G, OBERTACKE U: Extracellular ubiquitin inhibits the TNF $\alpha$ response to endotoxin in peripheral blood mononuclear cells and regulates endotoxin hyporesponsiveness in critical illness. Blood 101: 1882-1890, 2003.

MAJETSCHAK M, COHN SM, OBERTACKE U, PROCTOR KG: Therapeutic potential of exogenous ubiquitin during resuscitation from severe trauma. J Trauma 56: 991-1000, 2004.

MANIKIS P, JANKOWSKI S, ZHANG H, KAHN RJ, VINCENT JL: Correlation of serial blood lactate levels to organ failure and mortality after trauma. Am J Emerg Med 13: 619-622, 1995.

MANSOOR O, BEAUFRERE B, BOIRIE Y, RALLIERE C, TAILLANDIER D, AUROUSSEAU E, SCHOEFFLER P, ARNAL M, ATTAIX D: Increased mRNA levels for components of the lysosomal, $\mathrm{Ca}^{2+}$-activated, and ATP-ubiquitin-dependent proteolytic pathways in skeletal muscle from head trauma patients. Proc Natl Acad Sci USA 93: 2714-2718, 1996.

MENG L, MOHAN R, KWOK BH, ELOFSSON M, SIN N, CREWS CM: Epoxomicin, a potent and selective proteasome inhibitor, exhibits in vivo antiinflammatory activity. Proc Natl Acad Sci USA 96: 10403-10408, 1999. 
MOOMEY CB JR, MELTON SM, CROCE MA, FABIAN TC, PROCTOR KG: Prognostic value of blood lactate, base deficit, and oxygen-derived variables in an LD50 model of penetrating trauma. Crit Care Med 27: 154-161, 1999.

PATEL MB, MAJETSCHAK M: Distribution and interrelationship of ubiquitin proteasome pathway component activities and ubiquitin pools in various porcine tissues. Physiol Res 56: 341-350, 2007.

PHILLIPS JB, WILLIAMS AJ, ADAMS J, ELLIOTT PJ, TORTELLA FC: Proteasome inhibitor PS519 reduces infarction and attenuates leukocyte infiltration in a rat model of focal cerebral ischemia. Stroke 31: 1686-1693, 2000.

PLANK LD, HILL GL: Similarity of changes in body composition in intensive care patients following severe sepsis or major blunt injury. Ann N Y Acad Sci 904: 592-602, 2000.

PLANK LD, HILL GL: Energy balance in critical illness. Proc Nutr Soc 62: 545-552, 2003.

PONELIES N, KREHMEIER U, HIRSCH T, DENZ C, PATEL MB, MAJETSCHAK M: Cytosolic ubiquitin levels and ubiquitylation rates in human peripheral blood mononuclear cells during sepsis. Shock 24: 20-25, 2005.

RUSUNEN M, PUOLANNE E: Comparison of histochemical properties of different pig breeds. Meat Science 45: 119$125,1997$.

SAMY TS, SCHWACHA MG, CHUNG CS, CIOFFI WG, BLAND KI, CHAUDRY IH: Proteasome participates in the alteration of signal transduction in T and B lymphocytes following trauma-hemorrhage. Biochim Biophys Acta 1453: 92-104, 1999.

SEIFFERT M, GOSENCA D, PONELIES N, ISING N, PATEL MB, OBERTACKE U, MAJETSCHAK M: Regulation of the ubiquitin proteasome system in mechanically injured human skeletal muscle. Physiol Res 56: 227-233, 2007.

SHEN CA, CHAI JK, YAO YM, JIANG JH: Expression of mRNA and protein of ubiquitin in diaphragmatic muscle in burned rats with sepsis in early stage. Zhongguo Wei Zhong Bing Ji Jiu Yi Xue 15: 655-657, 2003.

SIGISMUND S, POLO S, Di FIORE PP: Signaling through monoubiquitination. Curr Top Microbiol Immunol 286: 149-185, 2004.

TAKAOKA M, ITOH M, HAYASHI S, KURO T, MATSUMURA Y: Proteasome participates in the pathogenesis of ischemic acute renal failure in rats. Eur J Pharmacol 384: 43-46, 1999.

TIAO G, FAGAN JM, SAMUELS N, JAMES JH, HUDSON K, LIEBERMAN M, FISCHER JE, HASSELGREN PO: Sepsis stimulates nonlysosomal, energy-dependent proteolysis and increases ubiquitin mRNA levels in rat skeletal muscle. J Clin Invest 94: 2255-2264, 1994.

TIAO G, HOBLER S, WANG JJ, MEYER TA, LUCHETTE FA, FISCHER JE, HASSELGREN PO: Sepsis is associated with increased mRNAs of the ubiquitin-proteasome proteolytic pathway in human skeletal muscle. J Clin Invest 99: 163-168, 1997.

WEISSMAN AM: Themes and variations on ubiquitylation. Nat Rev Mol Cell Biol 2: 169-178, 2001.

WILLMORE WG, STOREY KB: Multicatalytic proteinase activity in turtle liver: responses to anoxia stress and recovery. Biochem Mol Biol Int 38: 445-451, 1996.

\section{Corresponding author}

Matthias Majetschak, DeWitt Daughtry Family Department of Surgery, Division of Trauma and Surgical Critical Care, University of Miami Miller School of Medicine, 1800 NW 10th Ave., Miami, FL 33136, USA. Fax: ++1 3052437354.

E-mail: mmajetschak@med.miami.edu. 